\title{
Methods for assessing the efficiency of innovation activity of enterprises of the electric power industry
}

\author{
Valery Gusev ${ }^{1, *}$, Tatiana Naumkina ${ }^{1}$, Nikolay Voytolovskiy $^{2}$, Elena Minaeva ${ }^{3}$, Olga \\ Zemskova $^{4}$ \\ ${ }^{1}$ Moscow state University of technology and management. K.G. Razumovsky, Zemlyanoy Val street, \\ 73, Moscow, 109004, Russia \\ ${ }^{2}$ Sankt-Petersburg State Economic University, 21, Sadovaya street, St. Petersburg, 191023, Russia \\ ${ }^{3}$ Russian State University of Justice, 69, Novocheremushkinskaya street, 117418, Moscow, Russia \\ ${ }^{4}$ Moscow State University of Civil Engineering, 26, Yaroslavskoye shosse, Moscow, 129337, Russia
}

\begin{abstract}
The innovative basis for the development of the electric power industry is the basis for increasing the competitiveness of the economy as a whole. The purpose of the study is to develop a model for assessing the efficiency of innovation activity of enterprises of the electric power industry. The paper reveals a set of external macroeconomic factors that require adaptation of the innovation activity of the enterprise. A system of criteria for assessing the efficiency of innovation activity of enterprises of the electric power industry was developed. The approach to the selection of rational management decisions to improve the efficiency of innovation activity of enterprises of the electric power industry is substantiated. It assumes the choice of the reference enterprise based on the analysis of the state of innovation activity of the enterprise, as well as the assessment of the level and reserves of increasing the efficiency of innovation activity by group criteria.
\end{abstract}

\section{Introduction}

The innovation development of the domestic electric power industry is intended to ensure the passing of energy barriers of the country's economic growth, including by increasing the energy efficiency in the area of production, transportation and consumption, and expanding the use of alternative energy. The conducted studies have shown that innovation activity of the economic system is traditionally understood as the activity aimed at the commercialization of accumulated knowledge, technologies and equipment [1].

The essence of the assessment of the efficiency of innovation activity of the economic system is to determine the level and dynamics of the competitiveness of the economic system as a result of innovation activity.

\section{Materials and methods}

\footnotetext{
*Corresponding author: v.gusev991@,yandex.ru
} 
The paper shows that the content of the assessment of the efficiency of innovation activity (IA) of the economic systems is determined by the feature space presented in Table 1.

Table 1. Signs of space determining the content of the assessment of the efficiency of innovation activity of the economic systems.

\begin{tabular}{|c|c|c|}
\hline № & Feature & Components \\
\hline \multirow[t]{3}{*}{1} & \multirow{3}{*}{$\begin{array}{ll}\text { Efficiency for } & \text { the } \\
\text { participants } & \text { of } \\
\text { innovation processes } & \end{array}$} & $\begin{array}{l}\text { Assessment of the efficiency of IA from the perspective } \\
\text { of the manufacturer }\end{array}$ \\
\hline & & $\begin{array}{l}\text { Assessment of the efficiency of IA from the perspective } \\
\text { of the consumer }\end{array}$ \\
\hline & & $\begin{array}{l}\text { Assessment of the efficiency of IA from the perspective } \\
\text { of the investor }\end{array}$ \\
\hline \multirow[t]{5}{*}{2} & \multirow{5}{*}{$\begin{array}{l}\text { Integral efficiency of } \\
\text { innovation activity }\end{array}$} & Economic efficiency \\
\hline & & Scientific and technical efficiency \\
\hline & & Resource efficiency \\
\hline & & Social efficiency \\
\hline & & Ecological efficiency \\
\hline \multirow[t]{4}{*}{3} & \multirow[t]{4}{*}{ Innovative activity } & Cost indicators \\
\hline & & Indicators characterizing the dynamics of innovation \\
\hline & & Indicators of renewability \\
\hline & & Structural indicators \\
\hline \multirow[t]{8}{*}{4} & \multirow[t]{8}{*}{ Innovative capacity } & Level of scientific and technical reserve \\
\hline & & Resource capacity \\
\hline & & Financial capacity \\
\hline & & Infrastructure capacity \\
\hline & & Intellectual capacity \\
\hline & & Organizational capacity \\
\hline & & Entrepreneurial capacity \\
\hline & & Industrial capacity \\
\hline
\end{tabular}

The study of problems of assessing the efficiency of innovation activity of enterprises of the electric power industry showed that they are both general and specific. Among the general problems of assessing the efficiency of innovation activity of enterprises of the electric power industry, the following are distinguished. Firstly, the differentiation in the assessment of the efficiency of innovations of varying degrees of radicality has not been sufficiently elaborated under the stipulation that today imitative and modernizing innovations dominate in the Russian entrepreneurial environment.

Secondly, there are no private assessments related to the engineering innovations, knowledge economy innovations based on fundamental science, and assessments related to the quality of innovation management $[2,3]$.

Thirdly, at the current stage, the assessment of the efficiency of innovation activities of enterprises often comes down to either the assessment of statistical indicators of innovation activity, or to the assessment of the final results within certain aspects of innovation activity. Taking into account the principles for assessing the innovation activity of economic systems, the current trends in the development of assessment methods, as well as the identified key problems in assessing the innovation activity of enterprises of the electric power industry, an algorithm for their solution was developed. This algorithm is presented in Figure 1. 


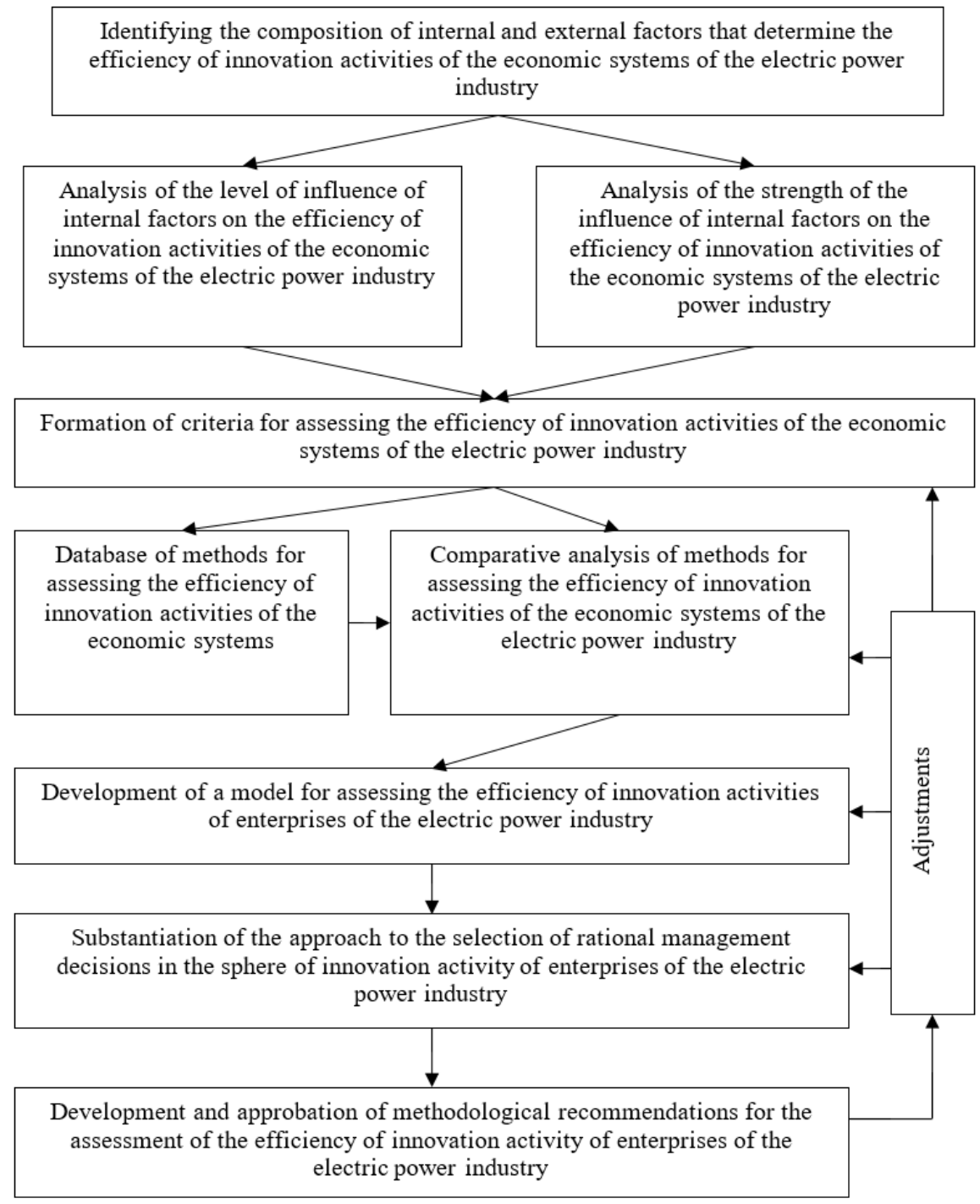

Fig. 1. Algorithm for solving the problem of assessing the innovation activity of the economic systems of the electric power industry.

As a result of the conducted studies, the set of external and internal factors of various degree of manageability determining the efficiency of innovation activity of enterprises of the electric power industry is highlighted (Table 2). The greatest positive influence on the efficiency of innovation activity of enterprises of the electric power industry is provided by the acquisition of new equipment, as well as education and training of personnel [4].

Table 2. Set of external and internal factors affecting the efficiency of innovation activity of enterprises of the electric power industry.

\begin{tabular}{|c|c|c|l|l|l|}
\hline \multicolumn{2}{|c|}{$\begin{array}{c}\text { External unmanageable macroeconomic } \\
\text { factors }\end{array}$} & \multicolumn{3}{c|}{$\begin{array}{c}\text { External partially manageable } \\
\text { microeconomic factors }\end{array}$} \\
\hline Economy & Politics & Legislation & $\begin{array}{l}\text { Local } \\
\text { authorities }\end{array}$ & Investors & $\begin{array}{l}\text { Fiscal } \\
\text { authorities }\end{array}$ \\
\hline Social & Cultural & Justice & Certification & Suppliers & Consumers \\
\hline
\end{tabular}




\begin{tabular}{|c|c|c|c|c|c|}
\hline $\begin{array}{c}\text { environmen } \\
t\end{array}$ & environment & & authorities & & \\
\hline $\begin{array}{l}\text { Climatic } \\
\text { conditions }\end{array}$ & $\begin{array}{l}\text { Geographical } \\
\text { conditions }\end{array}$ & $\begin{array}{l}\text { Environmenta } \\
1 \text { conditions }\end{array}$ & $\begin{array}{l}\text { Infrastructur } \\
\text { e (industrial, } \\
\text { transport, } \\
\text { information) }\end{array}$ & $\begin{array}{l}\text { Supply chain } \\
\text { intermediarie } \\
\mathrm{s}\end{array}$ & $\begin{array}{l}\text { Sales } \\
\text { intermediarie } \\
\mathrm{s}\end{array}$ \\
\hline $\begin{array}{l}\text { State of the } \\
\text { market }\end{array}$ & $\begin{array}{c}\text { Scientific and } \\
\text { technical } \\
\text { progress }\end{array}$ & $\begin{array}{l}\text { International } \\
\text { division of } \\
\text { labor and } \\
\text { foreign trade } \\
\text { relations }\end{array}$ & $\begin{array}{l}\text { Recruitment } \\
\text { agencies }\end{array}$ & $\begin{array}{l}\text { Market } \\
\text { (competitors) }\end{array}$ & $\begin{array}{l}\text { Consumer } \\
\text { unions }\end{array}$ \\
\hline \multicolumn{3}{|c|}{$\begin{array}{l}\text { Internal partially manageable } \\
\text { microeconomic factors }\end{array}$} & \multicolumn{3}{|c|}{$\begin{array}{l}\text { Internal fully manageable microeconomic } \\
\text { factors }\end{array}$} \\
\hline $\begin{array}{l}\text { Authorized } \\
\text { capital }\end{array}$ & $\begin{array}{c}\text { Legal } \\
\text { organizationa } \\
1 \text { form }\end{array}$ & $\begin{array}{c}\text { Issue of } \\
\text { securities }\end{array}$ & $\begin{array}{l}\text { Quality } \\
\text { system }\end{array}$ & Production & Finances \\
\hline Wage level & $\begin{array}{c}\text { Establishmen } \\
\mathrm{t} \text { of } \\
\text { intellectual } \\
\text { property } \\
\text { rights }\end{array}$ & $\begin{array}{l}\text { Conditions } \\
\text { for admission } \\
\text { and dismissal } \\
\text { of employees }\end{array}$ & Supply & $\begin{array}{l}\text { Management } \\
\text { system }\end{array}$ & Sale \\
\hline $\begin{array}{c}\text { Tax } \\
\text { deductions }\end{array}$ & $\begin{array}{c}\text { Labor } \\
\text { productivity }\end{array}$ & $\begin{array}{c}\text { Depreciation } \\
\text { deductions }\end{array}$ & Personnel & $\begin{array}{l}\text { Innovative } \\
\text { developments }\end{array}$ & Infrastructure \\
\hline \multicolumn{6}{|c|}{ Internal factors of innovation activity } \\
\hline $\begin{array}{c}\text { Research } \\
\text { and } \\
\text { developmen } \\
\mathrm{t} \\
\end{array}$ & $\begin{array}{l}\text { Acquisition } \\
\text { of new } \\
\text { equipment }\end{array}$ & $\begin{array}{l}\text { Acquisition of } \\
\text { new } \\
\text { technologies }\end{array}$ & $\begin{array}{l}\text { Acquisition } \\
\text { of software }\end{array}$ & $\begin{array}{l}\text { Education } \\
\text { and training } \\
\text { of personnel }\end{array}$ & $\begin{array}{l}\text { Acquisition } \\
\text { of rights to } \\
\text { patents and } \\
\text { licenses }\end{array}$ \\
\hline
\end{tabular}

Moderate positive influence on the efficiency of innovation activities of enterprises of the electric power industry is provided by the level of marketing research, as well as the acquisition of software. Negative influence on the efficiency of innovation activity of enterprises of the electric power industry is provided by: the level of conduction of their own research and development, the level of acquisition of new technologies and the level of novelty of the acquired rights to patents and licenses.

The conducted analytical studies of the influence of internal and external factors that determine the efficiency of innovation activity of enterprises of the electric power industry have demonstrated the need to develop criteria for assessing the efficiency of innovation activity of enterprises of the electric power industry that take into account not only its results but also the dynamics of the innovation processes that constitute innovation activity [5].

The integral criterion for assessing the efficiency of innovation activity of enterprises of the electric power industry $K_{\text {int }}$ was formulated in the process of research in the form of:

$$
K_{\text {int }}=K_{i c} \cdot K_{i a} \cdot K_{p r} \cdot K_{r i a},
$$

where $K_{i c}$ - assessment of innovation capacity, $K_{i a}$ - assessment of innovation activity, $K_{p r}$ - assessment of innovation processes, $K_{r i a}$ - assessment of the results of innovation activity.

The group criterion for assessing the results of innovation activity of the electric power enterprise demonstrates the combined strength of the positive effects that arise at the enterprise of the electric power industry with the implementation of innovation activity. 
On the basis of the above, we have developed a model for assessing the efficiency of innovation activitiy of enterprises of the electric power industry (Figure 2). The proposed model makes it possible to assess the efficiency of innovation activity of enterprises of the electric power industry of different functional orientation, which implement innovative changes of various types and varying degrees of radicality. At the same time, the components of innovation activity determine the choice of methods for assessment, while the specifics of the activity of enterprises and the characteristics of innovations determine the weight of the components of group assessments of the efficiency of innovation activity $[6]$.

\section{Results}

The obtained integral assessment of efficiency of innovation activity of enterprises of the electric power industry can be compared with integral assessment of efficiency of innovation activity of the reference enterprise on the regional, state and world level. Also it can be analyzed by group components.

Table 3. Model for assessing the efficiency of innovation activities of enterprises of the electric power industry.

\begin{tabular}{|c|c|c|c|c|c|c|c|c|}
\hline $\begin{array}{c}\text { Type of electric } \\
\text { power industry } \\
\text { enterprises }\end{array}$ & \multicolumn{2}{|c|}{$\begin{array}{l}\text { Generating } \\
\text { enterprises }\end{array}$} & \multicolumn{2}{|c|}{$\begin{array}{c}\text { Transportation } \\
\text { enterprises }\end{array}$} & \multicolumn{2}{|c|}{$\begin{array}{c}\text { Sales } \\
\text { enterprises }\end{array}$} & \multicolumn{2}{|c|}{$\begin{array}{l}\text { Repair and } \\
\text { service } \\
\text { enterprises }\end{array}$} \\
\hline & \multicolumn{8}{|c|}{ Description of innovation activity, including: } \\
\hline $\begin{array}{c}\text { Type of } \\
\text { innovation } \\
\text { changes }\end{array}$ & \multicolumn{2}{|c|}{ Production } & Technolog & ical & \multicolumn{2}{|c|}{ Organizational } & \multicolumn{2}{|c|}{ Market } \\
\hline $\begin{array}{l}\text { The level of } \\
\text { radicality of } \\
\text { innovation }\end{array}$ & \multicolumn{2}{|c|}{ Inventions } & Innovatic & & \multicolumn{2}{|c|}{ Modernizations } & \multicolumn{2}{|c|}{ Imitations } \\
\hline $\begin{array}{c}\text { Implementation } \\
\text { of the } \\
\text { components of } \\
\text { innovation } \\
\text { activities }\end{array}$ & \multicolumn{2}{|c|}{$\begin{array}{l}\text { Development of } \\
\text { innovative } \\
\text { capacity }\end{array}$} & $\begin{array}{r}\text { Manifestati } \\
\text { innovati } \\
\text { activity }\end{array}$ & $\begin{array}{l}\text { on of } \\
\text { on }\end{array}$ & \multicolumn{2}{|c|}{$\begin{array}{l}\text { Implementation } \\
\text { of innovation } \\
\text { processes }\end{array}$} & \multicolumn{2}{|c|}{$\begin{array}{l}\text { Achievement of } \\
\text { results of } \\
\text { innovation } \\
\text { activity }\end{array}$} \\
\hline $\begin{array}{l}\text { Selection of } \\
\text { methods for } \\
\text { assessing the } \\
\text { efficiency of } \\
\text { innovation }\end{array}$ & 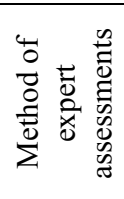 & 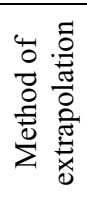 & 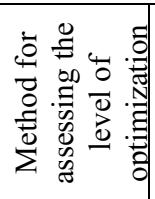 & 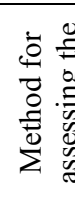 & 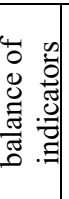 & 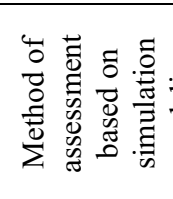 & 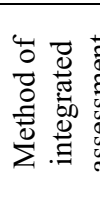 & 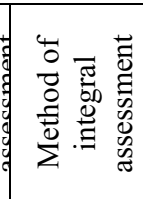 \\
\hline $\begin{array}{l}\text { Assessment of } \\
\text { the weight of } \\
\text { elements for the } \\
\text { components of } \\
\text { innovation } \\
\text { activity }\end{array}$ & \multicolumn{2}{|c|}{$\lambda_{i}$} & $\alpha_{j}$ & & & $\varphi_{w}$ & & $\mu_{s}$ \\
\hline $\begin{array}{c}\text { Assessment of } \\
\text { group } \\
\text { components of } \\
\text { innovation }\end{array}$ & \multicolumn{2}{|c|}{$K_{i c}$} & $K_{i a}$ & & & $K_{p r}$ & & $K_{r i a}$ \\
\hline
\end{tabular}




\begin{tabular}{|c|c|c|c|}
\hline activities & & & \\
\hline Result: & $\begin{array}{r}\text { Integral assessment of the efficiency of innovation activity of enterprises of } \\
\text { the electric power industry } K_{\text {int }}\end{array}$ \\
\hline
\end{tabular}

Taking into account the developed model for assessing the efficiency of innovation activities of enterprises of the electric power industry, the approach to selection of rational management decisions that improve the efficiency of innovation activity of enterprises of the electric power industry was substantiated. The algorithm that realizes the results of the substantiation of this approach is shown in Figure 3 [7].

On the basis of the analysis of innovation activity of enterprise of the electric power industry, the offered algorithm assumes a choice of the reference enterprise, an assessment of level and reserves of increase of efficiency of innovation activity by group criteria defined by the equation:

$$
\Delta K_{g r}=K_{g r}^{*}-K_{g r}>0
$$

where $K_{g r}^{*}$ - the assessed limit of the expected efficiency by the group criterion, achievable due to the management decisions implemented without additional investment.

The fact that integral assessment of the efficiency of innovation activity of the enterprise exceeds the reference level $\left(\mathrm{K}_{\mathrm{int}}>\mathrm{K}_{\mathrm{gr}}{ }^{\text {ref }}\right)$ indicates the expediency of the transition to the implementation of innovations of a higher level of radicality. If the management reserves are insufficient, then there is an objective need for additional targeted investment in the development of the components of innovation activity. 


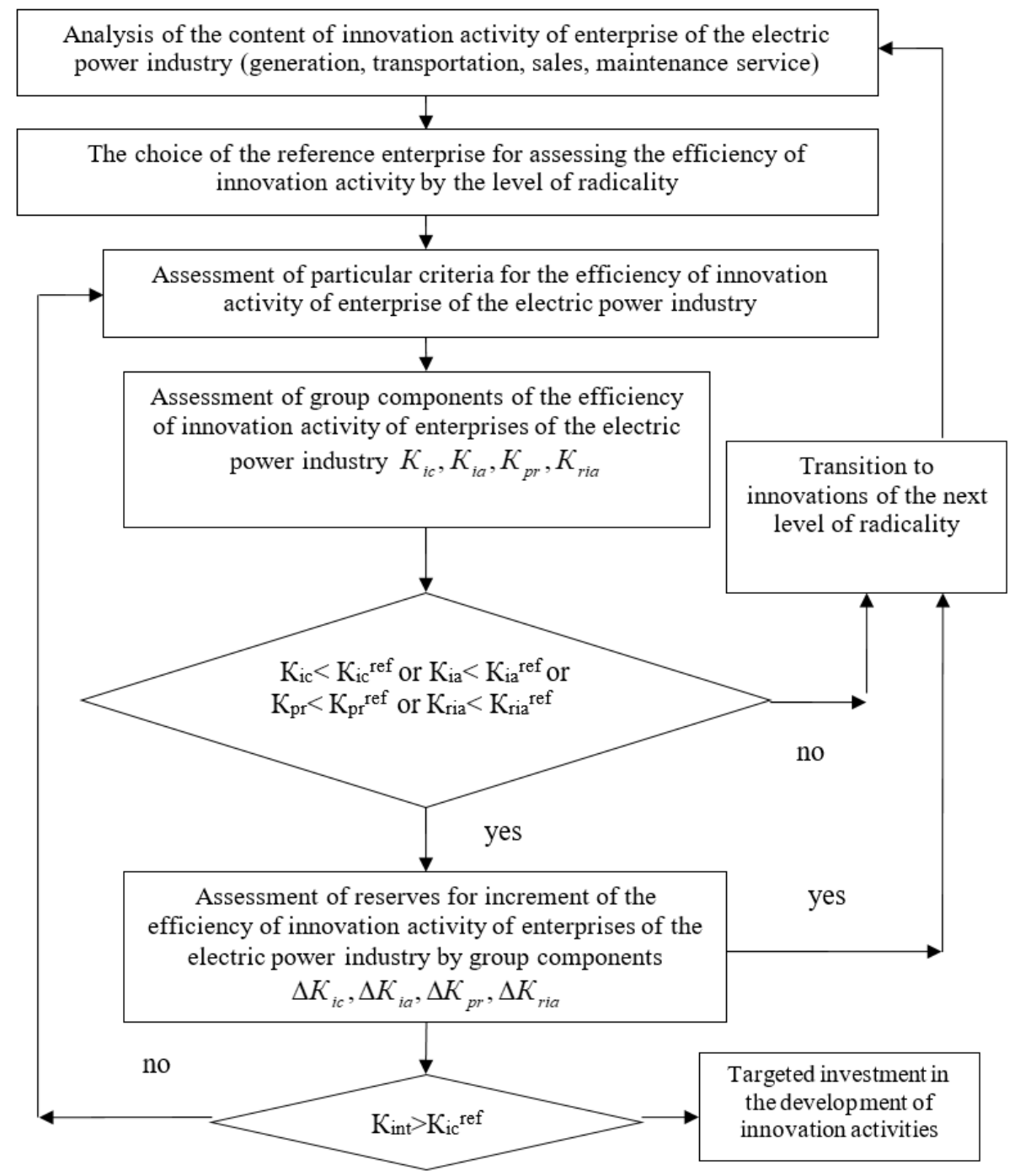

Fig. 2. Algorithm for increasing the efficiency of innovation activity of the electric power enterprise.

\section{Conclusion}

The identified problems of assessing the efficiency of innovation activity of enterprises of the electric power industry made it possible to develop an effective algorithm containing an analytical block (improving the criteria for assessing the efficiency of innovation activity of enterprises of the electric power industry), a synthetic block (substantiation of the approach to selection of rational management decisions to improve the efficiency of innovation activity of enterprises of the electric power industry) and a scientific and practical block (aimed at developing methodological recommendations to assess the efficiency of innovation activities of enterprises of the electric power industry).

The model for assessing the efficiency of innovation activity is proved. This model allows implementing the assessment of efficiency of the enterprises of various functional 
orientations, which conduct innovative changes of various types and various degree of radicality.

\section{References}

1. Y. Shin, D.-W. Kim, S.-W. Yang, H.-H. Cho, K.-I. Kang, ISARC 2008 - Proceedings from the 25th International Symposium on Automation and Robotics in Construction (2008)

2. Y. Kog, Practice Periodical on Structural Design and Construction (2008)

3. V. Kankhva, IOP Conf. Series: Earth and Environmental Science 90, 012175 (2017) doi:10.1088/1755-1315/90/1/012175

4. S.V. Domnina, E.V. Savoskina, N.V. Shekhova, Procedia Engineering 153, 741-746 (2016)

5. T. Simankina, M. Romanovich, O. Tsvetkov, MATEC Web of Conferences 53, 01054 (2016)

6. R. Lee, A. Lukin, Russia's Far East: New Dynamics in Asia Pacific and Beyond (Boulder, Colorado, 2016)

7. L. Ustinovicius, R. Rasiulis, L. Nazarko, T. Vilutienè, M. Reizgevicius, Procedia Engineering 122,166-171 (2015) 